\title{
ENZYME ACTIVITY OF FUNGI ASSOCIATED WITH STORED MAIZE GRAINS OBTAINED FROM SOME SELECTED FARMS NEAR BENIN CITY, NIGERIA
}

\author{
${ }^{* 1}$ Popoola, G. B. \& ${ }^{2}$ Okungbowa, F. I. \\ ${ }^{*}{ }^{2} 2$ Department of Plant Biology and Biotechnology Faculty of Life Sciences, University of Benin, P.M.B 1154, Benin City, \\ Edo State, Nigeria \\ *Corresponding Author's E-mail: francisca.okungbowa@ uniben.edu Phone: +2348055376204
}

\begin{abstract}
$\mathrm{G}$ lobal concern about food safety has led to increased interest in the study of food-spoilage fungi. Contaminated food affects human and animal health when such food items are consumed. This study was carried out to determine the fungi associated with stored corn in a bid to establishing their possible role in deterioration of corn. Using standard procedures, these fungi were isolated: Aspergillus, Trichoderma, Penicillium, and Rhizopus species. Results revealed the production of enzymes (protease, amylase, and lipase) by the fungi. The activity of these enzymes could play a role in the spoilage of corn by the fungi. In addition, the isolated fungi are known to be associated with postharvest yield losses in stored produce as well as producing toxins. Therefore, the data presented will help in choosing postharvest practices that will reduce contamination by these fungi. Protease activity values of the isolates ranged from $1.426 \pm 0.042-1.748 \pm 0.023 \mu \mathrm{ml}^{-1}$ (in Aspergillus sp.), $1.599 \pm 0.018$ $1.990 \pm 0.019 \mu \mathrm{ml}^{-1}$ (in Rhizopus sp.), $1.364 \pm 0.018-1.679 \pm 0.012 \mu \mathrm{ml}^{-1}$ (in Trichoderma sp.) and (1.544 \pm 0.017 $1.714 \pm 0.013 \mu \mathrm{ml}^{-1}$ (in Penicillium sp.). Amylase activity was highest in Rhizopus $\left(1.625 \pm 0.054-1.790 \pm 0.013 \mu \mathrm{ml}^{-}\right.$ ${ }^{1}$ ), followed by Penicillium sp and lowest in Aspergillus sp. Lipase activity was highest in Penicillium and lowest in Aspergillus. The detection and identification of fungi are crucial to developing appropriate management strategies for stored corn. Postharvest losses due to these fungi will lead to reduced income for the farmers.
\end{abstract}

Keywords: Characterization, Enzyme Activity, Isolation, Postharvest, Toxins, Stored Maize Grains

LICENSE: This article by African Journal of Health, Safety and Environment (AJHSE) is licensed and published under the Creative Commons Attribution License 4.0 International License, which permits unrestricted use, distribution, and reproduction in any medium, provided this article is duly cited.

COPYRIGHT: The Author(s) completely retain the copyright of this published article.

OPEN ACCESS: The Author(s) approves that this article remains permanently online in the open access (OA) model

QA: This Article is published in line with "COPE (Committee on Publication Ethics) and PIE (Publication Integrity \& Ethics)". 


\section{INTRODUCTION}

The world is concerned with food safety and this has enhanced interest in fungi and subsequently, food spoilage (Chilaka et al., 2012). Fungal spoilage of corn reduces the nutritional value and palatability of foods, thereby increasing its allergic potential and may result in mycotoxin contamination. Another issue is that some fungal species present in corn have been linked to mystic infection of cattle, particularly Aspergillus fumigatus (Griffin, 2010). Maize is one of the oldest human-cultivated crops, dating back to around the 15th century (Phoku et al., 2012).

Fungi can grow on grains in the field as well as in storage. Contamination of maize grains with fungi is regarded as one of the most serious safety problems in the tropical countries and throughout the world (Chilaka et al., 2012). Toxigenic fungi invading maize are divided into two distinct groups, field fungi and storage fungi. Field fungi invade maize and produce toxins before harvest or before the grains are threshed, and can develop under high relative humidity of over $80 \%$, with moisture content of $22 \%$ to $33 \%$ and a wide range of temperature $\left(10 \pm 35{ }^{\circ} \mathrm{C}\right)$. These fungi usually die out in storage, but some can live under storage conditions, cause significant damage, reducing the yield and quality, especially in warm humid climates (Dutton et al., 2013). Conversely, storage fungi invade grain primarily during storage and require moisture content in equilibrium with relative humidity of $70 \%$ to $90 \%$. In both circumstances, fungi originated from the field. Storage moulds replace field moulds that invade/ contaminate the maize before harvest. A number of fungal species are associated with stored grains; Fusarium, Penicillium, Rhizopus, Aspergillus and Tilletia species. (Egbuta et al., 2015). Infection of maize grain by storage fungi results in discoloration, dry matter loss, chemical and nutritional changes and overall reduction of maize grain quality. It has been reported by Mohale et al. (2013) that storage fungi contribute to loss of more than $50 \%$ of maize grain in tropical countries, and ranks second after insects as the major cause of deterioration and loss of maize.

According to Mulunda et al. (2013), when storage moulds invade maize grain they cause rot, kernel discoloration, loss of viability, mycotoxin contamination, and subsequent seedling blights. It was revealed that broken or mechanically damaged maize promotes development of storage moulds because fungi more easily enter the grain via the wounds (Ncube et al., 2011; Phoku et al., 2012; Saleemi et al., 2012).

Therefore, the study sought to isolate and identify the fungi associated with stored corn, and determine the enzyme activity of the species of fungi with a view to evaluating their impact on nutritional quality of the corn.

\section{MATERIALS AND METHODS COLLECTION AND SERIAL DILUTION OF SAMPLES}

Corn samples were collected from eight (8) farmers in Evboneka, Ukpoke, Iyowa and Ugbogiobo communities in Ovia North East Local Government Area (LGA), near Benin City, Edo State, the communities being among the major farming areas in the LGA. Samples were kept in clean polythene bags for laboratory analyses. Each corn sample was pounded in a mortar with pestle. Then $5 \mathrm{~g}$ of the pounded corn was transferred to a test tube and $5 \mathrm{ml}$ of water was added to form the stock. The mixture was sterilized at $121^{\circ} \mathrm{C}$ for $15 \mathrm{psi}$, allowed to cool and incubated for 7 days. Sterile McCartney bottles were divided and labeled $10^{1}$ to $10^{5}$ with each of the bottles (2 - 5) containing $9 \mathrm{ml}$ sterile distilled water. With a sterile pipette, $1 \mathrm{ml}$ each was transferred from the stock bottle into the first bottle and from the first bottle to the next until a dilution of $10^{5}$ was obtained. 


\section{ISOLATION AND IDENTIFICATION OF FUNGI ASSOCIATED WITH STORED CORN}

Using pour-plate method, $1 \mathrm{ml}$ of each serially diluted sample was transferred with a syringe into the corresponding labeled Petri dish. Then $9 \mathrm{ml}$ of PDA containing 10g/200ml chloramphenicol was dispensed into the Petri dish and plate was swirled gently for proper mixing of content. The plates were in duplicates and were incubated at room temperature $\left(28 \pm 2^{\circ} \mathrm{C}\right)$ for $72 \mathrm{hrs}$. Fungi associated with the maize samples were identified by using their cultural characteristics (Samson et al., 2002) and under a microscope fitted with a camera (Motic B1 Digital camera) using the cover-slip method in which a little quantity of each culture was transferred onto the base of a cover slip buried in PDA (Samson et al., 2002).

\section{DETERMINATION OF FUNGAL LOAD}

The microbial load of the samples was determined by visibly counting the colony forming units (CFU) after $72 \mathrm{hrs}$ of incubation. The morphological characterization of the isolates was also determined. The microbial load/ml was then determined by the formula shown below (Griffin, 2010).

$\begin{array}{llll}\text { Count } / \mathrm{ml}= & \text { No of colonies on plate } & \times & 1 \\ \text { Amount plated } & \text { dilution factor } & \text { Eqn. } 1\end{array}$

\section{Determination of percentage occurrence}

This was done using the formula stated below (Griffin, 2010).

$\%$ occurrence $=$ No of a particular isolate on plate $\times 100$

Total number of isolates on plate

Eqn. 2

1

\section{SUB-CULTURING OF FUNGI AND MAINTENANCE OF STOCK CULTURES}

Subcultures were made by carefully taking a growing portion of the old culture with a sterilized needle into a fresh PDA plate. The fresh culture plates were in duplicates and were incubated at room temperature for 72 hours. The fungal cultures were aseptically transferred into PDA slopes in McCartney bottles and stored at $5^{\circ} \mathrm{C}$ in a Gallenkamp incubator (Model 1H150).

\section{DETERMINATION OF ACTIVITY OF EXTRACELLULAR ENZYMES PRODUCED BY THE ISOLATED FUNGI}

The biochemical characterization of the isolated fungi was done by measuring the extracellular enzymes produced by the fungi in Czapeck dox broth. The broth was prepared by suspending $35 \mathrm{~g}$ of the medium in one liter of distilled water. The suspension was properly mixed using a magnetic stirrer with frequent agitation until complete dissolution. The suspension was dispensed into appropriate containers and autoclaved at $121^{\circ} \mathrm{C}$ for 15 minutes. 
Mycelial disc of 48-hour old culture of each fungus formed by using a cork borer of $5 \mathrm{~mm}$ in diameter, was introduced separately into $50 \mathrm{ml}$ of Czapeck dox broth. The broth was incubated at room temperature for 7 days for the fungus to grow. After the period of incubation, the mycelial mat was harvested by centrifuging the broth at 3000rpm for $15 \mathrm{~min}$. The supernatant served as a source of inoculum for the extracellular enzyme activity determination. The assayed enzymes were protease, amylase, and lipase, following the methods described below.

\section{QUANTITATIVE ESTIMATION OF $\alpha$ - AMYLASE}

This was done according to the method described by Yoo et. al. (1987) using starch powder as the enzyme substrate. Starch solution was prepared by weighing $0.15 \mathrm{~g}$ of starch powder into $300 \mathrm{ml}$ of phosphate buffer. The solution was boiled for $1 \mathrm{~min}$. Iodine solution was prepared by weighing $0.15 \mathrm{~g}$ of iodine crystals and $0.3 \mathrm{~g}$ of potassium iodide into $300 \mathrm{ml}$ of distilled water. Then $1 \mathrm{ml}$ of inoculum (obtained as explained above) was transferred into a McCartney bottle and $1 \mathrm{ml}$ of starch solution added. The reaction was stopped by adding $0.5 \mathrm{ml}$ of $0.1 \mathrm{~N} \mathrm{HCI}$ and then incubated for 30 minutes after which 3drops of iodine solution were added; the blue colour developed was read at $620 \mathrm{~nm}$.

\section{QUANTITATIVE ESTIMATION OF PROTEASE}

Casein was prepared by dissolving $1 \mathrm{~g}$ of casein (Merck quality) in a conical flask and 3 drops of sodium hydroxide solution and $80 \mathrm{ml}$ buffer solution were added. The mixture was stirred and heated to boil for $30 \mathrm{~min}$. The solution was allowed to cool and phosphate buffer solution was added to get a total volume of $100 \mathrm{ml}$. This was followed by preparation of $5 \%$ trichloroacetic acid (TCA) solution (16.4g TCA in $250 \mathrm{ml}$ of distilled water). The assay according to Kempka et al. (2008) was followed.

One millilitre of test sample was incubated at $25^{\circ} \mathrm{C}$ for 2 minutes, $1 \mathrm{ml}$ of casein solution was added and mixed well. The solution was left at room temperature for 10mins, after which $2 \mathrm{ml}$ of trichloroacetic acid was added and mixed thoroughly. The solution was incubated at $40^{\circ} \mathrm{C}$ for $10 \mathrm{~min}$, then filtered through a membrane filter and $5 \mathrm{ml}$ of sodium carbonate solution was added to $1 \mathrm{ml}$ of the filtrate followed by addition of $1 \mathrm{ml}$ of Folin's reagent. Incubation was done at $40^{\circ} \mathrm{C}$ for $20 \mathrm{mins}$, after which absorbance was read at $680 \mathrm{~nm}$. The following calculation was used to determine protease activity. One unit of protease was equivalent to the amount of enzyme required to release $1 \mu \mathrm{g}$ of tyrosine $/ \mathrm{ml} / \mathrm{min}$ under standard assay conditions.

Protease activity $(\mathrm{U} / \mathrm{ml})=\quad$ Absorbance $\mathrm{x}$ dilution factor $\mathrm{x}$ total volume

$$
\text { Reaction time }
$$

\section{QUANTITATIVE ESTIMATION OF LIPASE}

Lipase activity was determined titrimetrically on the basis of olive oil hydrolysis by the modified method of Kempka et al. (2008). One millilitre of culture supernatant was added to assay substrate, containing $5 \mathrm{ml}$ of $10 \%$ (v/v) homogenized olive oil in $10 \%$ (w/v) gum acacia, $1.0 \mathrm{ml}$ of $0.6 \% \mathrm{CaCl}_{2}$ solution and $5 \mathrm{ml}$ of phosphate buffer ( $\mathrm{pH} 7$ ). The enzyme- substrate mixture was incubated on a rotary shaker at $150 \mathrm{rpm}$ and $30^{\circ} \mathrm{C}$ for one hour. Then $5 \mathrm{ml}$ of alcohol: acetone (1:1) mixture was added to the reaction mixture. Liberated fatty acids were titrated with $0.1 \mathrm{~N} \mathrm{NaOH}$ 
using phenolphthalein as an indicator. The end point was light pink in colour. One unit of lipase was defined as the amount of enzyme which released one micro mole fatty acid per minute under specified assay conditions as shown below. Extracellular lipase activity was recorded as units per $\mathrm{ml}\left(\mathrm{U} \mathrm{ml}^{-1}\right)$ while intracellular activity was calculated in units per gram $\left(\mathrm{Ug}^{-1}\right)$.

Lipase activity $=\Delta \mathrm{V} \times \mathrm{N} \times 1000$

$\mathrm{V}_{\text {sample }} 60 \quad$ Eqn. 4

$\Delta \mathrm{V}=\mathrm{V}_{2}-\mathrm{V}_{1}$

$\mathrm{V} 1=$ Volume of $\mathrm{NaOH}$ used against control flask

$\mathrm{V} 2=$ Volume of $\mathrm{NaOH}$ used against experimental flask

$\mathrm{N}=$ Normality of $\mathrm{NaOH}$

$\mathrm{V}_{\text {(Sample) }}=$ Volume of enzyme extract

\section{RESULTS}

Fungi isolated from stored white corn collected from selected farms in Ovia North East LGA are presented in Table 1. They include Aspergillus, Trichoderma, Penicillium and Rhizopus species. Aspergillus species had the highest percentage occurrence of $40.3 \%$ followed by Penicillium (29.57) while Rhizopus had the least (7.53).The highest colony forming units (CFU) value was found in Aspergillus and the least, in Rhizopus. The fungi isolated from yellow corn are shown in Table 2.

Table 1: Fungi isolated from stored white corn collected from selected farms in Ovia North East LGA

\begin{tabular}{|c|c|c|c|}
\hline $\begin{array}{l}\text { Maize } \\
\text { Sample }\end{array}$ & $\mathrm{CFU} / \mathrm{ml}$ & Fungal Isolate & $\%$ Occurrence \\
\hline ASP (F1-8) & $75 \times 10^{5}$ & Aspergillus & 40.30 \\
\hline TRI (F1-6) & $42 \times 10^{5}$ & $\begin{array}{l}\text { species } \\
\text { Trichoderma } \\
\text { species }\end{array}$ & 22.58 \\
\hline PEN (F1-8) & $55 \times 10^{5}$ & $\begin{array}{l}\text { Penicillium } \\
\text { species }\end{array}$ & 29.57 \\
\hline RHI (F1-2) & $14 \times 10^{5}$ & $\begin{array}{l}\text { Rhizopus } \\
\text { species }\end{array}$ & 7.53 \\
\hline
\end{tabular}


Table. 2: Fungi isolated from stored yellow maize collected from selected farms in Ovia North East LGA

\begin{tabular}{llll}
$\begin{array}{l}\text { Maize } \\
\text { Sample } \\
\text { ASP (F1-8) }\end{array}$ & CFU/ml & Fungal Isolate & \% Occurrence \\
\hline TRI (F1-7) & $70 \times 10^{5}$ & $\begin{array}{l}\text { Aspergillus } \\
\text { Trichoderma } \\
\text { species }\end{array}$ & 36.46 \\
PEN(F1-8) & $85 \times 10^{5}$ & $\begin{array}{l}\text { Penicillium } \\
\text { species } \\
\text { Rhizopus } \\
\text { species }\end{array}$ & 24.31 \\
RHI (F1-6) & $28 \times 10^{5}$ & 9.72 \\
\hline
\end{tabular}

The enzyme activity of fungal isolates obtained from white and yellow corn for Day One is presented in Table 3. Protease activity of Rhizopus ranged from $0.729 \pm 0.017-1.333 \pm 0.011 \mu \mathrm{ml}^{-1}$, which was the highest. This was followed by Penicillium $\left(0.379 \pm 0.014-0.836 \pm 0.018 \mu \mathrm{ml}^{-1}\right)$, Aspergillus $\left(0.480 \pm 0.090-0.662 \pm 0.010 \mu \mathrm{ml}^{-1}\right)$ and Trichoderma $^{-}$ $\left(0.371 \pm 0.016-0.607 \pm 0.019 \mu \mathrm{ml}^{-1}\right)$. In the case of amylase, the activity was in the order: Rhizopus > Aspergillus > Trichoderma > Penicillium. The values for lipase activity were highest in Aspergillus (0.250 $\pm 0.017-0.500 \pm 0.011$ $\mu \mathrm{ml}^{-1}$ followed by Penicillium $(0.050 \pm 0.016-0.300 \pm 0.012)$ while Rhizopus $\left(0.050 \pm 0.016-0.200 \pm 0.018 \mu \mathrm{ml}^{-1}\right)$ and Trichoderma $\left(0.050 \pm 0.019-0.200 \pm 0.015 \mu \mathrm{ml}^{-1}\right)$ had similar activity

Table 3: Enzyme activity of fungal isolates from white and yellow corn on Day One

\begin{tabular}{llll}
\hline Isolate & Protease & Amylase & Lipase \\
\hline Aspergillus $(\mathrm{Y})$ & $0.662 \pm 0.010$ & $0.539 \pm 0.012$ & $0.500 \pm 0.011$ \\
Aspergillus (YC) & $0.512 \pm 0.030$ & $0.389 \pm 0.014$ & $0.350 \pm 0.013$ \\
Aspergillus (W) & $0.630 \pm 0.060$ & $0.639 \pm 0.016$ & $0.400 \pm 0.015$ \\
Aspergillus (WC) & $0.480 \pm 0.090$ & $0.489 \pm 0.018$ & $0.250 \pm 0.017$ \\
Rhizopus (Y) & $1.333 \pm 0.011$ & $0.505 \pm 0.013$ & $0.200 \pm 0.019$ \\
Rhizopus (YC) & $1.183 \pm 0.013$ & $0.355 \pm 0.016$ & $0.050 \pm 0.012$ \\
Rhizopus (W) & $0.879 \pm 0.015$ & $0.746 \pm 0.019$ & $0.100 \pm 0.014$ \\
Rhizopus (WC) & $0.729 \pm 0.017$ & $0.596 \pm 0.011$ & $0.050 \pm 0.016$ \\
Trichoderma (Y) & $0.607 \pm 0.019$ & $0.558 \pm 0.012$ & $0.200 \pm 0.018$ \\
Trichoderma (YC) & $0.457 \pm 0.012$ & $0.408 \pm 0.015$ & $0.050 \pm 0.010$ \\
Trichoderma (W) & $0.521 \pm 0.014$ & $0.655 \pm 0.016$ & $0.200 \pm 0.015$ \\
Trichoderma (WC) & $0.371 \pm 0.016$ & $0.505 \pm 0.019$ & $0.050 \pm 0.019$ \\
Penicillium (Y) & $0.836 \pm 0.018$ & $0.351 \pm 0.011$ & $0.300 \pm 0.012$ \\
Penicillium (YC) & $0.686 \pm 0.010$ & $0.201 \pm 0.014$ & $0.150 \pm 0.011$ \\
Penicillium (W) & $0.529 \pm 0.019$ & $0.434 \pm 0.015$ & $0.200 \pm 0.014$ \\
Penicillium (WC) & $0.379 \pm 0.014$ & $0.284 \pm 0.011$ & $0.050 \pm 0.016$ \\
\hline
\end{tabular}

Values are mean \pm SEM; $n=3$

Key: $\mathrm{Y}=$ yellow corn, $\mathrm{YC}=$ control /yellow corn, $\mathrm{W}=$ white corn, $\mathrm{WC}=$ control/white corn

The enzyme activity of fungal isolates obtained from white and yellow corn for Day Two is shown in Table 4. Protease activity was in the order: Rhizopus >Trichoderma >Aspergillus and Penicillium (which had similar values of 
$0.624 \pm 0.017-0.897 \pm 0.011 \mu \mathrm{ml}^{-1}$ and $0.738 \pm 0.011-0.896 \pm 0.015 \mu \mathrm{ml}^{-1}$, respectively). Amylase activity was highest in Penicillium $\left(0.774 \pm 0.019-1.501 \pm 0.016 \mu \mathrm{ml}^{-1}\right)$ and lowest in Trichoderma $\left(0.663 \pm 0.017-1.101 \pm 0.012 \mu \mathrm{ml}^{-1}\right) \mathrm{while}^{-10}$ lipase activity was highest in Penicillium $\left(0.250 \pm 0.016-0.500 \pm 0.010 \mu \mathrm{ml}^{-1}\right)$ and lowest in Aspergillus $(0.150 \pm 0.011$ $-0.350 \pm 0.013)$.

Table 4: Enzyme activity of fungal isolates from white and yellow on Day Two

\begin{tabular}{llll}
\hline Isolate & Protease & Amylase & Lipase \\
\hline Aspergillus (Y) & $0.897 \pm 0.011$ & $1.102 \pm 0.010$ & $0.300 \pm 0.013$ \\
Aspergillus (YC) & $0.729 \pm 0.013$ & $0.952 \pm 0.080$ & $0.150 \pm 0.011$ \\
Aspergillus (W) & $0.774 \pm 0.015$ & $1.179 \pm 0.016$ & $0.500 \pm 0.016$ \\
Aspergillus (WC) & $0.624 \pm 0.017$ & $1.029 \pm 0.015$ & $0.350 \pm 0.013$ \\
Rhizopus (Y) & $1.485 \pm 0.019$ & $1.325 \pm 0.014$ & $0.200 \pm 0.017$ \\
Rhizopus (YC) & $1.335 \pm 0.012$ & $1.175 \pm 0.012$ & $0.050 \pm 0.012$ \\
Rhizopus (W) & $1.079 \pm 0.014$ & $1.372 \pm 0.017$ & $0.350 \pm 0.015$ \\
Rhizopus (WC) & $0.929 \pm 0.016$ & $1.222 \pm 0.019$ & $0.400 \pm 0.013$ \\
Trichoderma (Y) & $0.693 \pm 0.018$ & $1.101 \pm 0.012$ & $0.250 \pm 0.011$ \\
Trichoderma (YC) & $0.543 \pm 0.010$ & $0.860 \pm 0.013$ & $0.250 \pm 0.016$ \\
Trichoderma (W) & $1.312 \pm 0.011$ & $0.813 \pm 0.016$ & $0.400 \pm 0.013$ \\
Trichoderma (WC) & $1.162 \pm 0.014$ & $0.663 \pm 0.017$ & $0.250 \pm 0.012$ \\
Penicillium (Y) & $0.896 \pm 0.015$ & $0.924 \pm 0.011$ & $0.400 \pm 0.013$ \\
Penicillium (YC) & $0.746 \pm 0.013$ & $0.774 \pm 0.019$ & $0.250 \pm 0.016$ \\
Penicillium (W) & $0.888 \pm 0.012$ & $1.501 \pm 0.016$ & $0.500 \pm 0.010$ \\
Penicillium (WC) & $0.738 \pm 0.011$ & $1.351 \pm 0.015$ & $0.350 \pm 0.011$ \\
\hline Values are mean \pm SEM & & & \\
\hline
\end{tabular}

Values are mean \pm SEM; $n=3$

Key:-Y=yellow corn, $\mathrm{YC}=$ control /yellow corn, $\mathrm{W}=$ white corn, $\mathrm{WC}=$ control/white corn.

The enzyme activity of fungal isolates obtained from white and yellow corn after three days is presented in Table 5 .

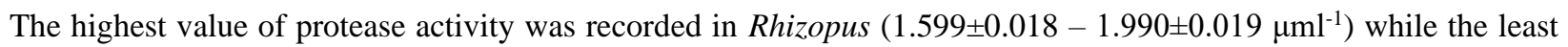
was found in Trichoderma $\left(1.364 \pm 0.018-1.679 \pm 0.012 \mu \mathrm{ml}^{-1}\right)$. Aspergillus $\left(1.426 \pm 0.042-1.748 \pm 0.023 \mu \mathrm{ml}^{-1}\right)$ and Penicillium $\left(1.544 \pm 0.017-1.714 \pm 0.013 \mu \mathrm{ml}^{-1}\right)$ had similar activity values. For lipase, activity values ranged from $0.350 \pm 0.016-0.700 \pm 0.012 \mu \mathrm{ml}^{-1}$ (Aspergillus), $0.550 \pm 0.013-0.700 \pm 0.018$ (Trichoderma), $0.550 \pm 0.015-$ $0.800 \pm 0.010$ (Rhizopus) to $0.650 \pm 0.011-0.800 \pm 0.012$ (Penicillium). 
Table 5: Enzyme activity of fungal isolates from white and yellow corn on day three

\begin{tabular}{|c|c|c|c|}
\hline Isolate & $\begin{array}{l}\text { Protease } \\
\left(\mu \mathrm{ml}^{-1}\right)\end{array}$ & $\begin{array}{l}\text { Amylase } \\
\left(\mu \mathrm{ml}^{-1}\right)\end{array}$ & $\begin{array}{l}\text { Lipase } \\
\left(\mu \mathrm{ml}^{-1}\right)\end{array}$ \\
\hline Aspergillus $(\mathrm{Y})$ & $1.748 \pm 0.023$ & $1.252 \pm 0.044$ & $0.700 \pm 0.012$ \\
\hline Aspergillus (YC) & $1.598 \pm 0.048$ & $1.102 \pm 0.036$ & $0.550 \pm 0.013$ \\
\hline Aspergillus (W) & $1.576 \pm 0.051$ & $1.426 \pm 0.049$ & $0.500 \pm 0.014$ \\
\hline Aspergillus (WC) & $1.426 \pm 0.042$ & $1.276 \pm 0.052$ & $0.350 \pm 0.016$ \\
\hline Rhizopus (Y) & $1.990 \pm 0.019$ & $1.775 \pm 0.061$ & $0.700 \pm 0.018$ \\
\hline Rhizopus (YC) & $1.850 \pm 0.015$ & $1.625 \pm 0.054$ & $0.550 \pm 0.013$ \\
\hline Rhizopus (W) & $1.749 \pm 0.016$ & $1.790 \pm 0.013$ & $0.700 \pm 0.015$ \\
\hline Rhizopus (WC) & $1.599 \pm 0.018$ & $1.640 \pm 0.018$ & $0.550 \pm 0.017$ \\
\hline Trichoderma $(\mathrm{Y})$ & $1.679 \pm 0.012$ & $1.666 \pm 0.013$ & $0.700 \pm 0.019$ \\
\hline Trichoderma (YC) & $1.529 \pm 0.019$ & $1.516 \pm 0.019$ & $0.550 \pm 0.015$ \\
\hline Trichoderma (W) & $1.514 \pm 0.014$ & $1.685 \pm 0.013$ & $0.800 \pm 0.010$ \\
\hline Trichoderma (WC) & $1.364 \pm 0.018$ & $1.535 \pm 0.085$ & $0.650 \pm 0.015$ \\
\hline Penicillium (Y) & $1.714 \pm 0.013$ & $1.535 \pm 0.030$ & $0.800 \pm 0.011$ \\
\hline Penicillium (YC) & $1.564 \pm 0.011$ & $1.385 \pm 0.025$ & $0.650 \pm 0.016$ \\
\hline Penicillium (W) & $1.694 \pm 0.013$ & $1.729 \pm 0.029$ & $0.800 \pm 0.012$ \\
\hline Penicillium (WC) & $1.544 \pm 0.017$ & $1.579 \pm 0.010$ & $0.650 \pm 0.011$ \\
\hline
\end{tabular}

Key: $\mathrm{Y}=$ yellow corn, $\mathrm{YC}=$ control /yellow corn, $\mathrm{W}=$ white corn, $\mathrm{WC}=$ control/white corn.

\section{DISCUSSION}

Some of the isolated fungi, especially Aspergillus, are known to contain species that produce toxins which may have adverse effects in plants, animals, and humans, as well as causing spoilage of food and feed (Wu et al., 2012). These fungi cause food spoilage during preharvest and postharvest stages of production, and release mycotoxins (Pavlova $e t$ al., 2011).

The results obtained from this study showed that various field and storage fungi are associated with stored maize. In addition, the analysis also showed contamination, predominantly by the four major toxigenic fungal genera. The CFU values were in the following range; yellow corn $(28-105 \mathrm{CFU} / \mathrm{ml})$ and white corn $\left(14 \times 10^{5}-75 \times 10^{5}\right.$ $\mathrm{CFU} / \mathrm{ml}$ ). The findings are in line with the study of Mahapatra and Banerjee (2012) who reported that the major fungal genera commonly encountered in maize-producing regions are Aspergillus and Penicillium spp. with count of $95 \times 10^{4}$ - $361 \times 10^{4}$ CFU. In line with the result of this study, Feng et al. (2010) reported that in Ethiopia various grain fungi including Fusarium, Penicillium, Aspergillus and Nigropora spp. have been detected in maize samples collected from Hawassa, Areka, Billito, Shallo and Arsi-Negele. The populations of all the fungi were higher in samples collected from farmers' stores than in the samples collected from research and seed multiplication stores. In the present study Aspergillus and Fusarium were frequently isolated from maize seeds and Penicillium was the second most frequent fungal genus. Charity et al. (2010) also identified four Fusarium species associated with maize grain in Nigeria. The major genera commonly encountered in maize grain in tropical regions are Fusarium, Aspergillus and Penicillium (Chulze, 2010).

Ortiz et al. (2010) reported that the development of these fungi can be affected by moisture content of the product, temperature, storage time and degree of fungal contamination prior to storage. Insect and mite activity facilitate fungi dissemination (Griffin, 2010). During storage, several kinds of fungi can remain associated with corn 
seeds either causing their deterioration or simply remaining viable to infect germinating seedling. The fungal genera typically found in stored grains are Aspergillus, Penicillium, Fusarium and some xerophytic species, several of them with capabilities of producing toxins (Adetunji et al., 2014). Aspergillus, Fusarium, Penicillium and Cladosporium are the predominant fungal genera associated with grains in storage (Chilaka et al., 2012). Aspergillus. flavus can infect maize pre- and post-harvest and an increase in aflatoxin content can occur if the phases of drying and storage are poorly managed (Dutton et al., 2013). Several phytopathogenic species of Fusarium are found to be associated with maize including $F$. verticillioides, F. proliferatum, F. graminearum and F. anthophilum (Mohale et al., 2013). Egbuta et al. (2015) reported that fungi from five genera (Aspergillus, Fusarium, Penicillium, Alternaria and Calviceps) are responsible for the production of the great majority of the mycotoxins that are of agricultural relevance (Mulunda et al., 2013). The losses caused by seed fungi may occur during seed development, storage or germination. Damage may result from loss of seed viability or from seedling infection following germination. Mulunda et al. (2013) also reported that Fusarium, Aspergillus and Penicillium were the most common genera isolated from maize samples collected around Shashemene and Alemaya. In general, the percentage occurrence of the different genera isolated showed the predominance of Aspergillus (38.46 - $40.30 \%$ ), Penicillium (22.58 - $24.31 \%$ ), Trichoderma (29.51 $29.57 \%$ ) and Rhizopus (20.51\%). This is in line with the study conducted by Phoku et al. (2012) which revealed the predominance of Penicillium species to be $57.2 \%$ in South African maize cultivars. Saleemi et al. (2012) reported that Penicillium spp. (34.5\%) are the most abundant genus after Fusarium spp. (65.5\%) in corn from Spain. Oda (2012) also reported Aspergillus spp. (20.1\%) at lower occurrence when compared to Penicillium species (40.9\%) and Fusarium spp. (39.0\%) in maize.

Results obtained for enzyme activity revealed the enzymes had different activity in different fungi. The results are also in line with those of Feijoo-Siota and Villa (2010) who reported that the enzyme activities of Aspergillus range from 0.986 - 1.411, while Penicillium was $0.601-1.691$. Yilmaz et al. (2016) stated that protease is an enzyme that catalyzes proteolysis, the breakdown of proteins into smaller polypeptides or single amino acids. They do this by cleaving the peptide bonds within proteins by hydrolysis, a reaction where water breaks bonds. Skoreński and Sieńczyk (2013) also reported that amylase is an enzyme that catalyses the hydrolysis of starch into sugars. They further stated that the presence of amylase can serve as an additional method of selecting for successful integration of a reporter construct in addition to antibiotic resistance. In addition Rejzek et al. (2011) reported that among a large number of non-pathogenic microorganisms capable of producing useful enzymes, filamentous fungi are particularly interesting due to their easy cultivation, and high production of extracellular enzymes of large industrial potential (Kundu et al., 2011). These enzymes are applied in the industry for detergents, starch, drinks, food, textile, animal feed, baking, pulp and paper, leather, chemical and for biomedical products.

\section{CONCLUSION}

This study has shown various fungi that affect stored corn, and how different enzymes are produced by the isolated fungi. Aspergillus species were the most predominant storage fungi followed by Penicillium species. These fungi are known for producing secondary metabolites (mycotoxins) which are carcinogenic to both humans and animals. Since these isolated fungi are very important in causing postharvest yield losses and production of mycotoxins, seed selection 
is useful in reducing the fungal load on seeds. Accurate detection and removal of infected seeds as well as identification of appropriate storage conditions that do not encourage fungal growth would help in reducing corn seed spoilage and postharvest losses.

\section{REFERENCES}

Adetunji, M. C., Atanda, O. O., Ezekiel, C. N. and Ogara, I. M. (2014). The distribution and mycotoxigenicity of fungal isolates of stored maize grains from five agro-ecological zones of Nigeria. Mycotoxicology 1: 19-28.

Charity, A., Amienyo, J. and Dauda, T. (2010). Effect of relative humidity on spore determination and growth of Aspergillus flavus. Nigerian Journal of Botany 23(1): 1-6.

Chilaka, C. A., De Kock, S., Phoku, J. Z., Mwanza, M. and Augustina, M. (2012). Fungal and mycotoxin contamination of South African commercial maize. Journal of Food, Agriculture and Environment. 10: 296303.

Chulze, S. N. (2010). Strategies to reduce mycotoxin levels in maize during storage: a review. Food Additives and Contaminants 27(5): 651-657.

Dutton, M. F., Andersson, G., Reiter, E. V., Razzazi-Fazeli, E. and Mwanza, M. (2013). The analysis of a feed component imported into South Africa for Aflatoxin in relation to fungal and mycotoxin contamination. Agricultural Science 1: 01-14.

Egbuta, M. A., Mwanza, M., Njobeh, P. B., Phoku, J. Z., Chilaka, C. A. and Dutton M. F. (2015). Isolation of filamentous fungi species contaminating some Nigerian food commodities. Journal of Food Research, 4: 38.

Feijoo-Siota, L. and Villa, T. G. (2010). Native and Biotechnologically Engineered Plant Proteases with Industrial Applications. Food and Bioprocess Technology 4(6): 1066-1088.

Feng, Y. L., Li, W. Q. and Wu, X. Q. (2010). Statistical optimization of media for mycelial growth and exopolysaccharide production by Lentinus edodes a kinetic model study of two growth morphologies. Biochemistry Journal 49(1): 104-112.

Griffin, A. (2010). As cited In: Suleiman, M. N. and Omafe, O. M. (2013). Activity Of Three Medicinal Plants On Fungi Isolated From Stored Maize Seeds (Zea Mays L.). Global Journal of Medicinal Plant Research 1(1): $77-81$

Kempka, A. P., Lipke, N. L., Pinheiro, T. L. F., Menoncin, S., Treichel, H., Freire, D. M. G., Luccio, M. and Oliveira, D. (2008). Response surface method to optimize the production and characterization of lipase from Penicillium verrucosum in solid state fermentation. Bioprocess Biosyst Eng 31: 119-125

. Kundu, S., Bhangale, A. S., Wallace, W. E., Flynn, K. M., Guttman, C. M., Gross, R. A. and Beers, K. L. (2011). Continuous Flow Enzyme-Catalyzed Polymerization in a Microreactor. Journal of the American Chemical Society 133(15): 6006-60011.

Mahapatra, S. and Banerjee, D. (2012). Structural elucidation and bioactivity of a novel exopolysaccharide from endophytic Fusarium solani $\mathrm{SD}_{5}$. Carbohydrate Polymer 90(1): 683-689.

Mohale, S., Medina, A., Rodríguez, A., Sulyok, M. and Magan N. (2013). Mycotoxigenic fungi and mycotoxins associated with stored maize from different regions of Lesotho. Mycotoxin Research 29: 209-219. 
Mulunda, M., Dzoma, B., Nyirenda, M. and Bakunzi, F. (2013). Mycotoxin's occurrence in selected staple food in main markets from Lubumbashi, Democratic Republic of Congo. Journal of Food, Agriculture and Environment 11: 51-54.

Ncube, E., Flett, B. C., Waalwijk, C. and Viljoen, A. (2011). Fusarium spp. and levels of fumonisins in maize produced by subsistence farmers in South Africa. South African Journal of Science 107: 33-39.

Oda, K. (2012). New families of carboxyl peptidases: serine-carboxyl peptidases and glutamic peptidases. Journal of Biochemistry 151(1): 13-25.

Ortiz, R., Taba, S., Chavez-Tovar, V. H., Mezzalama, M., Xu, Y., Yan, J. and Crouch, J. H. (2010). Conserving and Enhancing Maize Genetic Resources as Global Public Goods: A Perspective from CIMMYT. Crop Science 50: $13-28$.

Pavlova, K., Rusinova-Videva, S., Kuncheva, M., Kratchanova, M., Gocheva, M. and Dimitrova, S. (2011). Synthesis and characterization of an exopolysaccharide by Antarctic yeast strain Cryptococcus laurentii $\mathrm{AL}_{100}$. Applied Biochemistry and Biotechnology 163(8):1038-1052.

Phoku, J. Z., Dutton, M. F., Njobeh, P. B., Mwanza, M., Egbuta, M. A. and Chilaka, C. A. (2012). Fusarium infection of maize and maize-based products and exposure of a rural population to fumonisin B1 in Limpopo Province, South Africa. Food Additives and Contaminants 29: 1743-1751.

Rejzek, M., Stevenson, C. E., Southard, A. M., Stanley, D., Denyer, K., Smith, A. M., Naldrett, M. J., Lawson, D. M. and Field, R. A. (2011). Chemical genetics and cereal starch metabolism: structural basis of the non-covalent and covalent inhibition of barley $\beta$-amylase. Molecular BioSystems 7(3): 718-730.

Saleemi, M. K., Khan, M. Z., Khan, A., Javed, I. U., Hasan, Z., Hameed, M. R. and Mehmood M. A. (2012). Occurrence of toxigenic fungi in maize and maize-gluten meal from Pakistan. Phytopathologia Mediterranea 1: $219-224$

Samson, R. A., Hoekstra, E. S., Frisvad, J. C. and Filtenborg, O. (2002). Introduction to Food and Airborne Fungi, 6th Edition. African Journal of Microbiology Research. 3(2): 66-76.

Skoreński, M. and Sieńczyk, M. (2013). Viral proteases as targets for drug design. Current Pharmaceutical Design 19(6): 1126-1153.

Wu, S., Chen, J. and Pan, S. (2012). Optimization of fermentation conditions for the production of pullulan by a new strain of Aureobasidium pullulans isolated from sea mud and its characterization. Carbohydrate Polymer 87(2):1696-1700.

Yilmaz, N. K., Swanstrom, R. and Schiffer, C. A. (2016). Improving Viral Protease Inhibitors to Counter Drug Resistance. Trends in Microbiology 24(7): 547-557.

Yoo, Y. J., Hong, R.T., and Hatch, R. T. (1987). Comparison of alpha-amylase activities from different assay methods, Biotechnology Bioeng. 30(1):147-51. 